\section{Optimum Plot Size for Field Trials of Taro (Colocasia esculenta)}

\author{
Susan C. Miyasaka ${ }^{1}$ \\ University of Hawaii, College of Tropical Agriculture and Human Resources \\ (CTAHR), Department of Tropical Plant and Soil Sciences, 875 Komohana \\ Street, Hilo, HI 96720
}

Charles E. McCulloch
University of California, San Francisco, Department of Epidemiology and
Biostatistics, 185 Berry Street, Suite 5700, San Francisco, CA 94107

Graham E. Fogg

University of California, Davis, Department of Land, Air Water Resources, 237 Veihmeyer Hall, One Shields Avenue, Davis, CA 95616

James R. Hollyer

University of Hawaii, CTAHR, Agricultural Development in the American Pacific, 3050 Maile Way, Gilmore Hall 112, Honolulu, HI 96822

Additional index words. experimental design, statistics, tropical root crop

Abstract. Taro (Colocasia esculenta L. Schott) is a root crop widely grown in the Tropics. To determine the optimum plot size for taro field trials, fresh and dry weights of individual corms were collected from two field trials conducted under flooded culture and two conducted under upland culture. For a given maximum test plot with a single border row surrounding inner measured plants, all possible combinations of smaller plot sizes were investigated. A plot size was defined as a given number of adjacent plants. A strong linear relationship was found between the natural logarithm of variance of yield and the natural logarithm of plot size. Expressed on the non-log-transformed scale, the point of maximum curvature in this relationship indicates a sudden decrease in advantage to larger plot sizes and is taken as optimum. Calculating maximum curvature mathematically, optimum plot size was 21 inner plants $\left(5.7 \mathrm{~m}^{2}\right)$ for the second flooded trial and 18 inner plants $\left(4.9 \mathrm{~m}^{2}\right)$ for the second upland trial. Another method of estimating optimum plot size minimized the cost per unit of research data by using the index of degree of correlation between neighboring plots. In three of four trials, the optimum plot size ranged from 16 to 24 inner plants $\left(4.3\right.$ to $\left.6.5 \mathrm{~m}^{2}\right)$. In this second method, we calculated a non-linear relationship between plot size and outer border plants to estimate the fixed and per-unit cost of a single border row surrounding the inner measured plants. Both methods of calculating optimal plot size sometimes resulted in estimates that exceeded the maximum test plot size for particular field trials, indicating limitations of each method and the importance of managing field trials to ensure uniformity across treatments. No evidence of spatial autocorrelation was found in the corm yield of taro, indicating that the two methods used were adequate in calculating optimum plot size. In addition, we conducted an analysis based on statistical power but found that plot size did not materially affect the power to detect differences between treatments. To our knowledge, this is the first report of optimum plot size for field trials of taro.
Taro (Colocasia esculenta) is the fifth most harvested root crop in the world with production estimated at 9.0 million $t$ for 2011 (Food and Agriculture Organization of the United Nations, 2012). It is a tropical root crop that is grown primarily for its starchy, underground stem (i.e., corm), although leaf blades and petioles are eaten also (Plucknett et al., 1970). Corms are good sources of carbohydrates with easily digestible starch and have a favorable protein-to-energy ratio (Standal, 1983).

Taro is traditionally planted using vegetative propagules and is grown under flooded (i.e., wetland) conditions or non-flooded (i.e., upland) conditions (Plucknett et al., 1970). Typically, it is grown for six to 13 months.
Field trials are expensive to conduct both in terms of material inputs and time. There is a need to determine the minimum research plot size that will determine adequate yield characteristics as affected by various management options. In general, there are four methods for calculating optimum plot size (defined as number of measured plants in a plot): 1) determine maximum curvature of the relationship between variance of yield and plot size (Lessman and Atkins, 1963; Meier and Lessman, 1971; Smith, 1938); 2) minimize cost per unit of information (Smith, 1938; Swallow and Wehner, 1986; Zuhlke and Gritton, 1969); 3) use geostatistics to account for spatial autocorrelation in experimental design (Fagroud and Van Meirvenne, 2002); and 4) determine the plot size that maximizes the power to differentiate treatments.

Smith's (1938) "law" was based on the empirical observation that a linear relationship was found between the logarithm of residual variance among plot means and the logarithm of plot size. When estimating mean yields from normally distributed data, the Fisher information is proportional to the inverse of the variance (Zucker, 2005), so modeling the variance is tantamount to modeling the Fisher information. Smith (1938) found that the variance (or equivalently the information) is often linear as described in Eq. [1].

$$
\log \left(\mathrm{V}_{\mathrm{x}}\right)=\log \left(\mathrm{V}_{1}\right)-\mathrm{b} \times \log (\mathrm{x})
$$

where $V_{x}=$ variance of means of contiguous plots of size $x, V_{1}=$ variance of a plot of smallest possible size, and $\mathrm{x}=$ plot size as a multiple of the smallest possible size.

The coefficient "b" can then be interpreted as an index of degree of correlation between neighboring plots because it measures how quickly the variance decreases with increasing plot size.

Often, optimum plot size has been estimated visually based on the maximum curvature in the plot of $\mathrm{V}_{\mathrm{x}}$ vs. $\mathrm{x}$ (Boyhan et al., 2003; Vallejo and Mendoza, 1992); however, the apparent curvature in a figure plotting $\mathrm{V}_{\mathrm{x}}$ Vs. $\mathrm{x}$ is sensitive to the relative scaling in the $y$ - and $\mathrm{x}$-axes of the plot (Smith, 1938). Curvature is a well-defined mathematical concept and it is straightforward (see "Materials and Methods") to determine the point of maximum curvature. Subjective, visual interpretation of the point of maximum curvature, as it appears that several previous publications have used, is often incorrect, sometimes significantly so.

Smith's (1938) method estimated optimum plot size for unguarded plots (i.e., no border rows) based on an index of soil heterogeneity ("b") and cost considerations (based on hours of labor). Larger plots could provide marginally more information about production attributes than smaller plots, but there is increased cost associated with increased plot size as described in Eq. [2].

$$
\mathrm{X}_{\mathrm{opt}}=\mathrm{b} \times \mathrm{K}_{1} /\left[(1-\mathrm{b}) \times \mathrm{K}_{2}\right]
$$

where $X_{\text {opt }}=$ optimum plot size, $b$ is from Eq. [1], $\mathrm{K}_{1}=$ cost per plot for costs that do not depend on plot size, and $\mathrm{K}_{2}=$ cost per unit area for costs that increase with plot size. 
The empirical method of Smith (1938) calculates a constant index of soil heterogeneity ("b"); however, if spatial autocorrelation between data points exist, then " $b$ " may not be constant (Zhang et al., 1990). Spatial autocorrelation means that lower variances are found for observations separated by short distances compared with those separated by long distances (van Es and van Es, 1993). Fagroud and Van Meirvenne (2002) simulated 24 plot configurations, calculated variograms of each plot, and determined that the plot with the maximum nugget/sill ratio as the optimum plot size for a field experiment in Morocco.

A fourth method of determining the optimum plot size is based on the plot size and number of replications needed to detect a specific difference between treatments (Hatheway, 1961). Using uniformity data, the true difference between two treatments (expressed as a percent of the mean) is plotted against plot size and number of replications. The experimenter could decide on the desired difference between treatment means and then could estimate the plot size and number of replicates from the graph to detect this difference (Boyhan et al., 2003; Hatheway, 1961). This analysis was termed a power analysis, because it is related to the probability of finding a difference between treatments that does exist.

There is no previous literature discussing optimum plot size for field trials of taro. We hypothesized that: 1) flooded conditions would reduce moisture stress, resulting in more uniform growing conditions, reduced variability in yield, and reduced optimum plot size compared with upland conditions; 2) cultivars would differ in variability of yield, resulting in different requirements for optimum plot size; and 3) tissue-cultured planting materials would be more uniform in growth and exhibit less variance than traditional "huli" (i.e., stem cuttings).

Sweet potato (Ipomoea batatas Lam.) is a tropical root crop, and Vallejo and Mendoza (1992) plotted the relationship between the
$\mathrm{CV}$ of yield and plot size using the maximum curvature method to visually estimate an optimum plot size of 30 to 60 plants covering 6 to $12 \mathrm{~m}^{2}$. Among several methods, Boyhan et al. (2003) visually estimated maximum curvature and calculated optimum plot size for short-day onions (Allium cepa $\mathrm{L}$.) to be 280 to 320 plants covering 19 to $22 \mathrm{~m}^{2}$. Based on the power analysis of Hatheway (1961), Boyhan et al. (2003) estimated an optimum plot size of 240 plants or $11 \mathrm{~m}^{2}$ and six replicates or an optimum plot size of 480 plants or $22 \mathrm{~m}^{2}$ and three replicates. Using a segmented regression model to estimate the point of maximum curvature, Nokoe and Ortiz (1998) estimated optimum plot size for banana (Musa spp.) as 10 to 16 plants. Using a mathematical solution to the maximum curvature method, Meier and Lessman (1971) found an optimum plot size of $5.35 \mathrm{~m}^{2}$ for the oil seed [Crambe hispanica L. subsp. abyssinica (Hochst. ex R.E.Fr.) Prina]; in contrast, based on Eq. [2], they found a larger optimum plot size of $6.7 \mathrm{~m}^{2}$. Using the method of minimized cost per unit of information, Zuhlke and Gritton (1969) calculated optimum plot size for peas (Pisum sativum L.) of $3.3 \mathrm{~m}^{2}$ for unguarded plots and $3.1 \mathrm{~m}^{2}$ for guarded plots. Using Eq. [2], Swallow and Wehner (1986) found optimum plot size for conventionally harvested cucumbers (Cucumis sativus L.) ranged from 0.7 to $3.8 \mathrm{~m}^{2}$. Fagroud and Van Meirvenne (2002) found spatial autocorrelation in measurements of available water capacity in a field in Morocco, and they recommended a plot size of $4 \times 8 \mathrm{~m}\left(32 \mathrm{~m}^{2}\right)$ based on geostatistics.

The objective of this study was to determine the optimum plot size for field experiments of taro conducted either under flooded or non-flooded (upland) conditions and to compare the various methods of determination. We compared two methods of estimating optimum plot size and showed the importance of mathematically determining maximum curvature in the first method. In the second method, we developed a novel procedure of calculating the cost of border rows. In addition, we conducted geostatistical analysis, including variography and visual inspection of maps of the dry weight of corms grown under both flooded and upland conditions, and found no evidence of spatial autocorrelation. Finally, we examined the effect of plot size on the power of differentiating treatment means and found little effect of plot size on two statistical parameters used to estimate power.

\section{Materials and Methods}

Copper taro Trials 1 and 2 (flooded). To determine optimal plot size, eight extra plots were inserted into two field trials determining the effects of copper $(\mathrm{Cu})$ on taro. The plots contained 110 plants ( 10 rows $\times 11$ plants) of taro cv. Maui Lehua (commercial, modern Hawaiian taro cultivar) spaced at $0.60 \mathrm{~m} \times$ $0.45 \mathrm{~m}$ for a maximum plot size of $29.7 \mathrm{~m}^{2}$ (see Table 1 for a summary). A single border row surrounded the inner 72 plants (eight rows $\times$ nine plants) that were measured for individual corm yields. Vegetative propagules of taro ("huli" or lower $30 \mathrm{~cm}$ of petiole and upper $0.5 \mathrm{~cm}$ of corm) were planted in flooded paddies. Two plots each were exposed to treatments that consisted of zero and eight applications of cupric sulfate at $1.2 \mathrm{~kg} \cdot \mathrm{ha}^{-1} \cdot \mathrm{cm}^{-1}$ of water level in the paddy (numbered 1 and 4 , respectively). These two treatments were repeated four times and labeled as blocks A to D. Planting date for Trial 1 was 22 Mar. 1995 and 22 to 23 Apr. 1996 for Trial 2. Duration of growth was 13 months after planting (MAP) in Trial 1 and 10 MAP in Trial 2.

Location of the trial was at the University of Hawai'i Paddy Crop Research Station in Kapaa, Kauai, HI (lat. 22.09 $\mathrm{N}$, long. $159.34^{\circ} \mathrm{W}$ ). The soil is in the Hanalei series (very fine, mixed, semiactive, nonacid, isohyperthermic, Typic Endoaquept) (Ikawa et al., 1985; National Resource Conservation Service, 2012). Soil $\mathrm{pH}$ of aerated soil was 4.60 (in $\mathrm{H}_{2} \mathrm{O}$ ) (Ikawa et al., 1985); however, lime was not added because soil $\mathrm{pH}$ is known to increase on flooding.

Table 1. Summary of four field trials of taro conducted under flooded ( $\mathrm{Cu}$ taro Trials 1 and 2) and upland (white taro Trials 1 and 2 ) conditions.

\begin{tabular}{|c|c|c|c|c|}
\hline & $\mathrm{Cu}$ taro 1 & $\mathrm{Cu}$ taro 2 & White taro 1 & White taro 2 \\
\hline Culture & Flooded & Flooded & Upland & Upland \\
\hline Cultivar & 'Maui Lehua' & 'Maui Lehua' & 'Bun Long' and 'Mana Lauloa' & 'Bun Long' and 'Mana Lauloa' \\
\hline $\begin{array}{l}\text { Total no. of maximum } \\
\text { plots measured }\end{array}$ & 8 & 8 & 11 & 16 \\
\hline $\begin{array}{l}\text { Total no. of plants per } \\
\text { maximum plot }\end{array}$ & $110(10$ rows $\times 11$ plants $)$ & $110(10$ rows $\times 11$ plants $)$ & $112(8$ rows $\times 14$ plants $)$ & $72(6$ rows $\times 12$ plants $)$ \\
\hline $\begin{array}{l}\text { Inner plants measured } \\
\text { per maximum plot }\end{array}$ & 72 (8 rows $\times 9$ plants $)$ & 72 (8 rows $\times 9$ plants $)$ & $60(6$ rows $\times 10$ plants $)$ & $40(4$ rows $\times 10$ plants $)$ \\
\hline Treatments & $2 \mathrm{Cu}$ levels & $2 \mathrm{Cu}$ levels & 2 cvs. and 2 planting dates & 2 cvs. and 2 prop. methods \\
\hline Planting date & 22 Mar. 1995 & 22-23 Apr. 1996 & 15 Mar. 1994 and 12 May 1994 & 19 June 1996 and 25 July 1996 \\
\hline Crop cycle & $\begin{array}{l}13 \text { months after planting } \\
\text { (MAP) }\end{array}$ & 10 MAP & 9 MAP & 9 MAP \\
\hline Location & Kapaa, Kauai & Kapaa, Kauai & Onomea, HI & Hakalau, HI \\
\hline Soil series & Hanalei series & Hanalei series & Hilo series & Hilo series \\
\hline Spacing & $0.45 \mathrm{~m} \times 0.6 \mathrm{~m}$ & $0.45 \mathrm{~m} \times 0.6 \mathrm{~m}$ & $0.3 \mathrm{~m} \times 0.9 \mathrm{~m}$ & $0.3 \mathrm{~m} \times 0.9 \mathrm{~m}$ \\
\hline Maximum plot size & $29.7 \mathrm{~m}^{2}$ & $29.7 \mathrm{~m}^{2}$ & $30.2 \mathrm{~m}^{2}$ & $19.4 \mathrm{~m}^{2}$ \\
\hline Maximum air temp. & $24-29^{\circ} \mathrm{C}$ & Not determined (ND) & $24-28^{\circ} \mathrm{C}$ & $21-28^{\circ} \mathrm{C}$ \\
\hline Minimum air temp. & $17-22^{\circ} \mathrm{C}$ & ND & $17-22^{\circ} \mathrm{C}$ & $16-22{ }^{\circ} \mathrm{C}$ \\
\hline Problems & None & $\begin{array}{l}\text { Low starch content } \\
\text { of corms at harvest }\end{array}$ & Wild pig damage in 5 plots & Inadequate rainfall in second MAP \\
\hline
\end{tabular}

$\mathrm{Cu}=$ copper 
Table 2. All possible combinations of plot sizes in $\mathrm{Cu}$ taro Trials 1 and 2 with 72 inner measured plants in the maximum plot size.

\begin{tabular}{lcc}
\hline $\begin{array}{l}\text { No. of inner } \\
\text { plants in } \\
\text { y-dimension (w) }\end{array}$ & $\begin{array}{c}\text { No. of inner } \\
\text { plants in } \\
\text { x-direction (d) }\end{array}$ & $\begin{array}{c}\text { No. of inner } \\
\text { plants in } \\
\text { plot }\left(w^{*} \text { d) }\right.\end{array}$ \\
\hline 1 & 1 & 1 \\
1 & 3 & 3 \\
1 & 9 & 9 \\
2 & 1 & 2 \\
2 & 3 & 6 \\
2 & 9 & 18 \\
4 & 1 & 4 \\
4 & 3 & 12 \\
4 & 9 & 36 \\
8 & 1 & 8 \\
8 & 3 & 24 \\
\hline
\end{tabular}

$\mathrm{Cu}=$ copper; $\mathrm{w}=$ width; $\mathrm{d}=$ depth.
For Trial 1, fertilizer $(16 \mathrm{~N}-6.5 \mathrm{P}-12.5 \mathrm{~K}$ analysis) was applied in equal amounts (560 $\mathrm{kg} \cdot \mathrm{ha}^{-1}$ ) at 1,3 , and 5 MAP and $10 \mathrm{~N}-2.2 \mathrm{P}$ $26.6 \mathrm{~K}$ fertilizer was applied in equal amounts $\left(560 \mathrm{~kg} \cdot \mathrm{ha}^{-1}\right)$ at 7 and 9 MAP for a total of $380 \mathrm{~kg}$ nitrogen $(\mathrm{N})$ per ha, $135 \mathrm{~kg}$ phosphorus $(\mathrm{P})$ per ha, and $510 \mathrm{~kg}$ potassium $(\mathrm{K})$ per ha. In an attempt to increase corm yields, fertilizer rates were increased in Trial 2 with fertilizer $(16 \mathrm{~N}-6.5 \mathrm{P}-12.5 \mathrm{~K}$ analysis $)$ applied in equal amounts $\left(560 \mathrm{~kg} \cdot \mathrm{ha}^{-1}\right)$ at $1,2,3,4,5$, and $6 \mathrm{MAP}$ and fertilizer $(10 \mathrm{~N}-2.2 \mathrm{P}-26.6 \mathrm{~K}$ analysis) applied $\left(560 \mathrm{~kg} \cdot \mathrm{ha}^{-1}\right)$ at $7 \mathrm{MAP}$ for a total of $600 \mathrm{~kg} \mathrm{~N}$ per ha, $230 \mathrm{~kg} P$ per ha, and $570 \mathrm{~kg} \mathrm{~K}$ per ha. Weeds were controlled by hand-weeding.

Air temperatures (maximum and minimum) were recorded with an automated data logger
(CR10; Campbell Scientific, Logan, UT) during $\mathrm{Cu}$ Trial 1. Maximum air temperatures ranged between a high of $29^{\circ} \mathrm{C}$ during Sept. 1995 and a low of $24{ }^{\circ} \mathrm{C}$ during Feb. 1996. Minimum air temperatures ranged between a high of $22^{\circ} \mathrm{C}$ during Sept. 1995 and a low of $17^{\circ} \mathrm{C}$ during Mar. 1996. Rainfall data was not considered relevant because taro was grown under flooded culture. No weather data were collected during $\mathrm{Cu}$ Trial 2 as a result of equipment failure.

Taro were harvested early at 10 MAP in $\mathrm{Cu}$ Trial 2, because it was observed that corms were developing a condition called "loliloli" in which starch was translocated out of the storage organ, resulting in poor eating quality and an increasingly greater susceptibility to rot. One possible reason for the "loliloli"
00000000000000

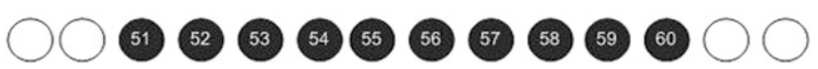

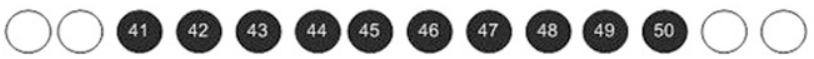

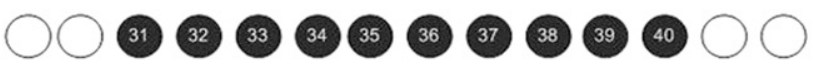

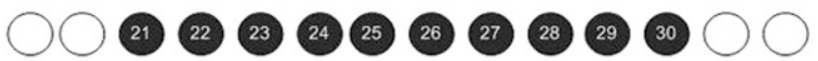

$0 \bigcirc$ (1) (1) (3) (3) (3) (1) (1) (1) (1) (1) 20 $\bigcirc 0$

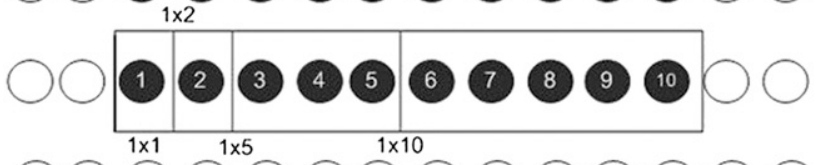

00000000000000

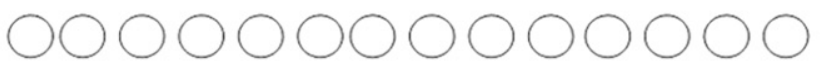

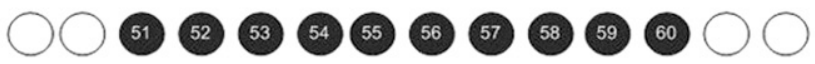

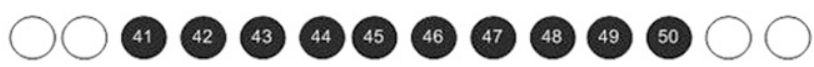

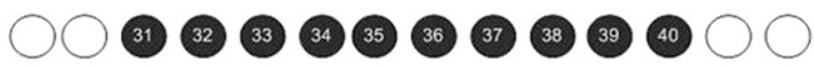

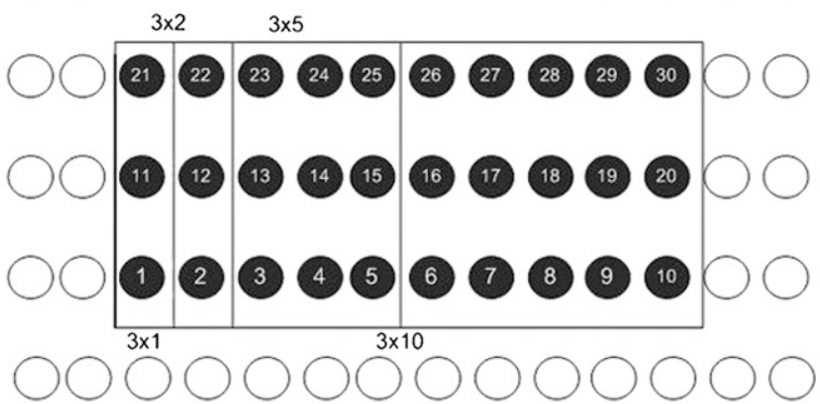

00000000000000

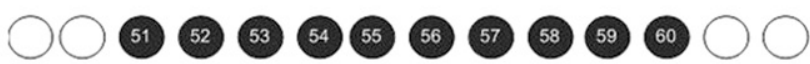

O

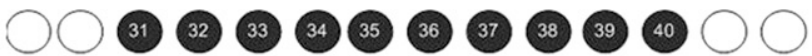

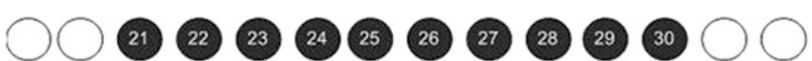

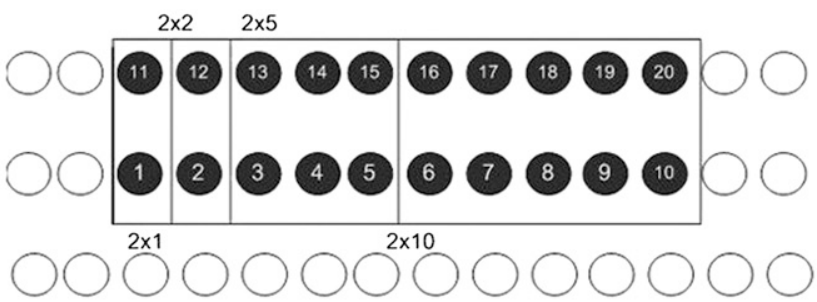

Fig. 1. All possible plot sizes (one, two, three, five, six, 10, 12, 15, 20, and 30) for white taro Trial 1. 
condition of corms observed in $\mathrm{Cu}$ Trial 2 could have been flooding at the experimental site at 8 MAP that resulted in excess nutrients stimulating plant regrowth during the maturation phase and starch removal from corms.

Individual main corms from the inner 72 plants were harvested, washed, and weighed. Rotten portions of corms were removed and corms reweighed, because commercial yields of taro are based on fresh weight of corms with rotten portions removed. A subsample was taken, weighed, dried to a constant weight at $55{ }^{\circ} \mathrm{C}$, and reweighed to calculate average percent dry matter. Dry weight of corms without rot was estimated by multiplying fresh weight of corms (with rot removed) by the dry matter fraction. It was decided that the best measure of yield and disease resistance was corm yield on a dry weight basis with rot removed, because this parameter is related to both fresh weight yield and an estimate of starch content.

White taro Trials 1 and 2 (upland). To determine optimal plot size, eight extra plots of each cultivar were added to an upland, rainfed field trial (white taro Trial 1) that compared two cultivars of taro, cvs. Bun Long (commercial, Chinese taro cultivar) and Mana Lauloa (traditional Hawaiian taro cultivar that produces relatively white corms and flour). Plots contained 112 plants (eight rows $\times 14$ plants) at a spacing of $0.9 \mathrm{~m} \times 0.3 \mathrm{~m}$ for a maximum plot size of $30.2 \mathrm{~m}^{2}$. There were four border plants per row and one border row, and the inner 60 plants (six rows $\times 10$ plants) were measured individually for corm yield (Table 1). Four plots of each cultivar were planted on 15 Mar. 1994 (winter planting) and 12 May 1994 (spring planting) using tissuecultured plantlets that had been grown in the nursery for approximately three months. Total number of plots to evaluate optimal plot size was eight per cultivar; unfortunately, as a result of wild pig damage, usable data were not measured in all plots of cv. Bun Long planted during the spring and one plot of cv. Mana Lauloa planted during the spring, resulting in a total of four measured plots for cv. Bun Long and seven measured plots for $\mathrm{cv}$. Mana Lauloa.

To estimate optimal plot size, eight additional plots of each cultivar were added into white taro Trial 2 that compared two taro cvs., Bun Long and Mana Lauloa. Each plot contained 72 plants (six rows $\times 12$ plants) at a spacing of $0.9 \mathrm{~m} \times 0.3 \mathrm{~m}$ for a maximum plot size of $19.4 \mathrm{~m}^{2}$ with one border row surrounding the inner measured 40 plants (four rows $\times 10$ plants).

Each cultivar was planted into four plots using vegetative propagules ("huli") and four plots using tissue-cultured plantlets that had been grown in the nursery for three months. As a result of a delay in obtaining sufficient planting materials, two blocks of Trial 2 were planted on 19 June 1996 and two blocks on 25 July 1996. Plants were harvested at 9 MAP for both trials.

The location of Trial 1 was at Onomea, HI (lat. $19.84^{\circ} \mathrm{N}$, long. $155.11^{\circ} \mathrm{W}$ ) and that of

Table 3. Labor, equipment, and materials costs per basic research plot size (one taro plant), including the cost of border rows, for $\mathrm{Cu}$ taro trials (flooded) and white taro trials (upland).

\begin{tabular}{|c|c|c|c|c|}
\hline \multirow[b]{2}{*}{ Operation } & \multicolumn{2}{|c|}{$\mathrm{Cu}$ taro } & \multicolumn{2}{|c|}{ White taro } \\
\hline & $\mathrm{K}_{1}^{\mathrm{z}}$ & $\mathrm{K}_{2}^{\mathrm{y}}$ & $\mathrm{K}_{1}$ & $\mathrm{~K}_{2}$ \\
\hline Plowing & 0.023 & 0.0069 & 0.023 & 0.0069 \\
\hline Paddy preparation & 0.023 & 0.37 & 0 & 0 \\
\hline Irrigation supplies & 0.018 & 0.073 & 0 & 0 \\
\hline Planting materials & 0 & 0.25 & 0 & 0.65 \\
\hline Fertilizer A1 & 0 & 0 & 0.035 & 0.071 \\
\hline Fertilizer TSP & 0 & 0 & 0.0071 & 0.036 \\
\hline Fertilizer $16 \mathrm{~N}-15 \mathrm{P}-15 \mathrm{~K}$ & 0.017 & 0.017 & 0 & 0 \\
\hline Fertilizer $10 \mathrm{~N}-5 \mathrm{P}-32 \mathrm{~K}$ & 0.011 & 0.011 & 0 & 0 \\
\hline Dolomite & 0 & 0 & 0.0023 & 0.068 \\
\hline Goal & 0 & 0 & 0.117 & 0 \\
\hline Fencing & 0 & 0 & 0.094 & 0.071 \\
\hline Labor-experimental plan & 0.11 & 0 & 0.11 & 0 \\
\hline Labor-clearing ditch & 0.11 & 0 & 0 & 0 \\
\hline Labor-planting & 0.058 & 0.31 & 0.039 & 0.051 \\
\hline Labor-fertilizing & 0.019 & 0.026 & 0.087 & 0.090 \\
\hline Labor-line preparation & 0 & 0 & 0.0096 & 0.026 \\
\hline Labor-fence & 0 & 0 & 0.0094 & 0.041 \\
\hline Labor-weeding & 0.0029 & 0.026 & 0.0096 & 0.013 \\
\hline Labor-spraying & 0 & 0 & 0.013 & 0.013 \\
\hline Labor-irrigation & 0.095 & 0.064 & 0.019 & 0.025 \\
\hline Subtotal 1 & 0.490 & 1.150 & 0.610 & 1.160 \\
\hline Border rows ${ }^{x}$ & 9.230 & 0.580 & 9.300 & 0.580 \\
\hline Labor-harvest & 0.058 & 0.62 & 0.029 & 0.077 \\
\hline Labor-data collection & 0.030 & 0.43 & 0.030 & 0.16 \\
\hline Labor-data analysis & 0.055 & 0 & 0.055 & 0 \\
\hline Subtotal 2 & 9.860 & 2.780 & 10.020 & 1.980 \\
\hline
\end{tabular}

${ }^{\mathrm{z}} \mathrm{K}_{1}=$ costs per plot that are independent of plot size; units are in U.S. dollars at the time of the field trials. ${ }^{\mathrm{y}} \mathrm{K}_{2}=$ costs per plot that increase with plot size.

${ }^{x}$ Fixed cost was based on a minimum of eight border plants per plot size of one plant; costs per plot was based on Eq. [6].

$\mathrm{Cu}=$ copper; $\mathrm{TSP}=$ triple superphosphate.

Trial 2 at Hakalau, HI (lat. $19.90^{\circ} \mathrm{N}$, long. $\left.155.16^{\circ} \mathrm{W}\right)$. At both sites, the soil was in the Hilo series (Medial over hydrous, ferrihydritic, isohyperthermic, acrudoxic Hydrudands) (National Resource Conservation Service, 2012). Soil $\mathrm{pH}$ (in $\mathrm{H}_{2} \mathrm{O}$ ) ranged from 5.8 to 6.4.

At each site before planting, $4500 \mathrm{~kg} \cdot \mathrm{ha}^{-1}$ of $\mathrm{CaCO}_{3}$ equivalents (consisting of $20 \%$ dolomite and $80 \%$ crushed coral) were applied then plowed into the soil to a depth of $15 \mathrm{~cm}$. Phosphorus was banded in planting lines at $680 \mathrm{~kg} P$ per ha as triple superphosphate; this high rate was used because this volcanic ash soil is known to be P-fixing (i.e., $\mathrm{P}$ is unavailable to plants). Fertilizer ( $23 \mathrm{~N}-0 \mathrm{P}-$ $29.9 \mathrm{~K}$ analysis) was broadcast at planting and again monthly in equal amounts $\left(1120 \mathrm{~kg} \cdot \mathrm{ha}^{-1}\right)$ up through 5 MAP for a total application of $1550 \mathrm{~kg} \mathrm{~N}$ per ha and $2010 \mathrm{~kg} \mathrm{~K}$ per ha. This fertilizer rate was intentionally high to make up for the expected losses resulting from the high annual rainfall in this geographic area that typically exceeds $3000 \mathrm{~mm}$. The preemergent herbicide, oxyfluorfen [2-chloro-1(3-ethoxy-4-nitrophenoxy)-4-(trifluoromethyl) benzene] (Goal 1.6 E; Rohm and Haas Co., Philadelphia, PA), was applied after planting at $0.56 \mathrm{~kg}$ a.i. per ha. Rainfall and air temperatures (maximum and minimum) were recorded daily for both white taro trials (Campbell Scientific). During white taro Trial 1, maximum air temperatures ranged from a high of $28{ }^{\circ} \mathrm{C}$ during Aug. 1994 to a low of $24{ }^{\circ} \mathrm{C}$ during Mar. 1994. Minimum air temperatures ranged from a high of $22{ }^{\circ} \mathrm{C}$ during
Aug. 1994 and a low of $17{ }^{\circ} \mathrm{C}$ during Feb. 1995. During white taro Trial 2, maximum air temperatures ranged from a high of $28{ }^{\circ} \mathrm{C}$ during Aug. 1996 to a low of $21^{\circ} \mathrm{C}$ during Jan. 1997. Minimum air temperatures ranged from a high of $22^{\circ} \mathrm{C}$ during Nov. 1996 and a low of $16^{\circ} \mathrm{C}$ during Jan. 1997.

Taro was grown under rainfed, upland conditions, requiring $\approx 70 \mathrm{~mm}$ of rainfall per month for optimum growth. Sufficient rainfall occurred during white taro Trial 1, except during the harvest month when rainfall is not as critical for taro growth. For white taro Trial 2 , however, inadequate rainfall occurred during the second MAP. Although hand-watering was conducted, plant mortality averaged $40 \%$ as a result of drought stress.

At 9 MAP, 60 individual corms were harvested per plot in Trial 1 and 40 individual corms per plot in Trial 2. Dead corms were treated as missing data. The same harvesting procedures were followed as in the $\mathrm{Cu}$ trials.

Calculation of optimum plot size using maximum curvature. In each of the four trials, plot sizes were formed by amalgamating adjacent plants into all possible rectangular plots of different sizes that would evenly divide up the whole plot while excluding border rows and border plants. These combinations differed depending on the total plot size and arrangement of plants within a plot for each trial. In $\mathrm{Cu}$ taro Trials 1 and 2, all possible plot sizes consisted of one, two, three, four, six, eight, nine, $12,18,24$, and 36 plants (Table 2). In white taro Trial 1, all possible 
sizes were one, two, three, four, five, six, 10, $12,15,20$, and 30 plants (Fig. 1). In white taro Trial 2, all possible plot sizes included one, two, four, five, eight, 10 , and 20 plants.

The variance of total dry weight of corm minus rot was calculated across replications for each plot size. In this article, we used the natural logarithm $(\ln )$ rather than the $\log$ in Eq. [1] (Smith, 1938). The ln of the variance at that plot size was graphed against the $\ln$ of the plot size to estimate a linear relationship (PROC GLM; SAS Version 9.1; SAS Institute Inc., 2010). Preliminarily, this method was performed separately for each treatment, but later the results were combined after determining that the variance to plot size relationship was similar across treatments.

A relationship of the form of Eq. [1], namely $\ln \left(\mathrm{V}_{\mathrm{x}}\right)=\ln \left(\mathrm{V}_{1}\right)-\mathrm{b} \times \ln (\mathrm{x})$, implies that the variance is given by:

$$
\mathrm{V}_{\mathrm{x}}=\mathrm{V}_{1} \times(\mathrm{x})^{-\mathrm{b}} \text {. }
$$

On the nonlinear variance scale, as the plot size increases, variance decreases and begins to level off. Mathematically, curvature is defined as the rate of change of the angle of a tangent to the curve as a point moves along a curve (Ellis and Gulick, 1972) and it is calculated mathematically by using the first and second derivatives (denoted $y^{\prime}$ and $y^{\prime \prime}$, respectively) of any equation as follows:

$$
\text { Curvature }=\frac{y^{\prime \prime}}{\left(1+y^{\prime 2}\right)^{3 / 2}} .
$$

For Eq. [3], the derivatives are:

$$
\begin{aligned}
& y^{\prime}=-b V_{1} x^{-b-1}, \text { and } \\
& y^{\prime \prime}=-b(-b-1) V_{1} x^{-b-2}
\end{aligned}
$$

where $\mathrm{y}=$ variance, $\mathrm{x}=$ plot size, and $\mathrm{b}=$ is from Eq. [1].

Calculation of optimum plot size based on minimized cost per unit of research information. In the $\mathrm{Cu}$ trials, labor and equipment costs were recorded for site preparation, paddy construction, planting, weeding, fertilizing, irrigating, harvesting, experimental planning, data collection, and data analysis (Table 3). Material costs were recorded for planting materials ("huli") and fertilizers. Examples of costs per plot that are considered independent of plot size $\left(\mathrm{K}_{1}\right)$ for this experiment are labor costs of transportation to the experimental site, time to set-up and then clean-up for a particular activity (such as initially placing fertilizers in buckets and then cleaning out buckets when finished), clearing of the irrigation ditch, experimental planning, and data collection and analysis. In addition, the cost for the first bag of fertilizer was considered to be a fixed cost. Examples of costs per plot that increased with plot size $\left(\mathrm{K}_{2}\right)$ are costs of planting materials, fertilizers (after the first bag), water, labor for planting, fertilizing, weeding, and harvesting each plant, and border rows after the minimum number of eight plants.

Smith's (1938) formula for guarded plots required knowledge of the area of end border rows as well as the ratio of the width of border

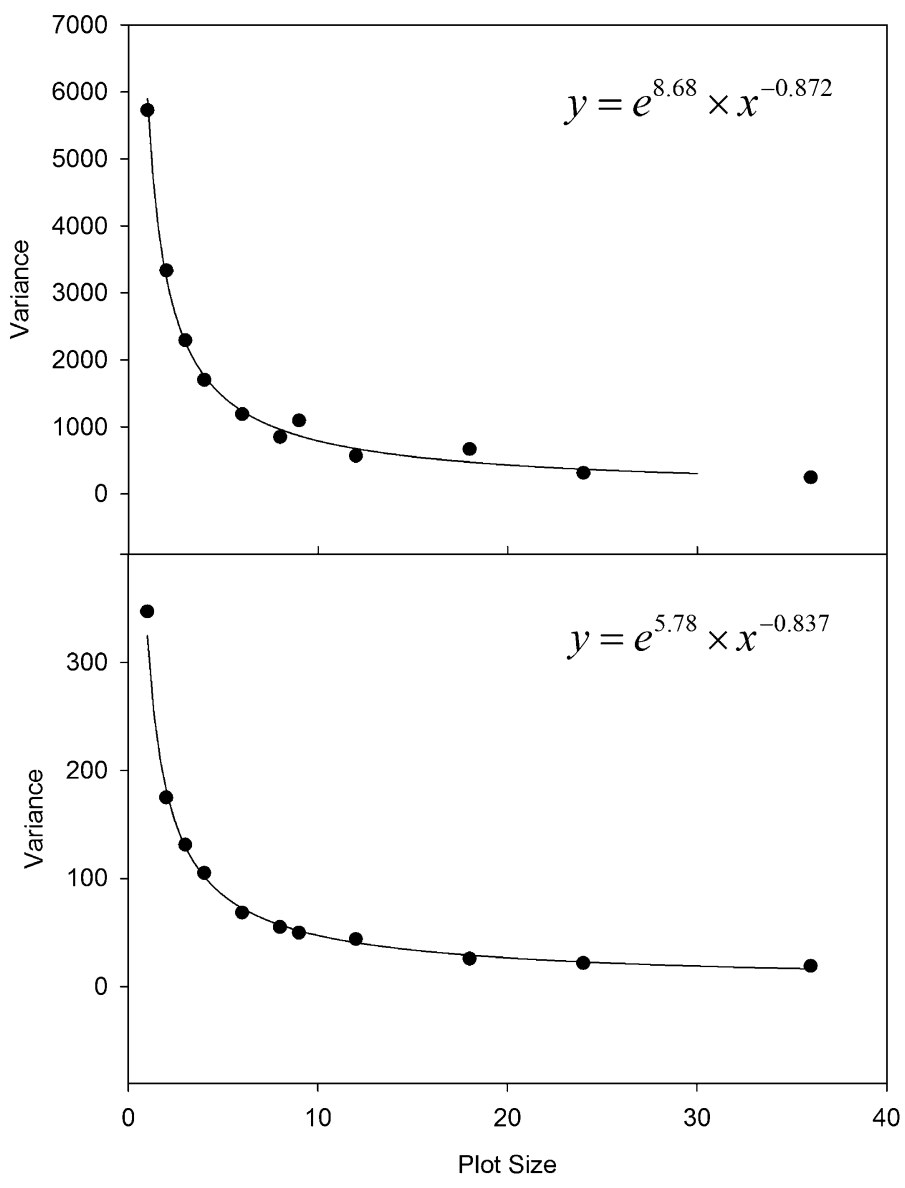

Fig. 2. Top, relationship of variance to plot size in copper $(\mathrm{Cu})$ taro Trial 1. Bottom, relationship for $\mathrm{Cu}$ taro Trial 2. Data points are means of variance for particular plot sizes averaged across treatments.

rows relative to that of the test area. Instead, we calculated $\mathrm{K}_{1}$ and $\mathrm{K}_{2}$ costs for border rows as follows. If the inner, measured plants are laid out in a rectangle of width (w) and depth $(d)$, there are $d \times$ w plants surrounded by $(2 \times d)+(2 \times w)+$ four border row plants. The fixed cost was estimated based on eight border plants (i.e., minimum number of border plants surrounding a plot size of one plant). To estimate the increase in border plants as the number of inner plants increased, denote the ratio $\mathrm{d} / \mathrm{w}$ by $\lambda$. Then, the number of inner measured plants would equal $\mathrm{d} \times \mathrm{w}$ or $\lambda \times \mathrm{w}^{2}$ and the number of outer border plants minus eight would equal $(2 \times d)+(2 \times w)-4$. Substituting for $d$, the number of outer border plants minus eight would be $2 \times \mathrm{w} \times(\lambda+1)-4$. Substituting for $w$, the number of outer border plants minus eight would result in the following equation:

Outer $=2 \sqrt{\text { Inner }} \times[\sqrt{\lambda}+1 / \sqrt{\lambda}]-4$ or

Outer $=t+s(\lambda) \times \sqrt{\text { Inner }}$

where Outer $=$ number of outer border plants minus eight, Inner = number of inner measured plants, $\lambda=$ ratio of $\mathrm{d} / \mathrm{w}, \mathrm{d}=$ number of inner plants in $\mathrm{x}$ direction, $\mathrm{w}=$ number of inner plants in $\mathrm{y}$ direction, and $\mathrm{s}$ and $\mathrm{t}$ are coefficients.
Using regression (PROC GLM; SAS Institute Inc., 2010) of Outer on the square root of Inner, we found the single best approximating coefficients $t$ and $s(\lambda)$ that worked across the values of $d$ and $w$ for our field layout.

In the white taro trials, costs of labor, equipment, and materials were similar to the $\mathrm{Cu}$ trials (Table 3 ) with the following exceptions: paddies and irrigation lines were not prepared, herbicides were applied to control weeds, different fertilizer types and amounts were applied, fencing was installed to prevent pig damage to the crop, and tissue-cultured plantlets were used as propagating materials. Optimum plot size was calculated based on Eq. [2] and Smith's (1938) "b" calculated from Eq. [1].

Calculation of semivariograms to quantify spatial autocorrelation. Often observations taken close to each other are more similar than those taken farther apart. Geostatistics allow for the calculation of variance of the variable $\mathrm{Y}$ as a function of distance as follows (van Es and van Es, 1993; Zhang et al., 1990):

$$
\operatorname{Var}\left(\mathrm{Y}_{\mathrm{i}+\mathrm{h}}-\mathrm{Y}_{\mathrm{i}}\right)=2 \gamma(\mathrm{h})
$$

where $\mathrm{Y}_{\mathrm{i}+\mathrm{h}}-\mathrm{Y}_{\mathrm{i}}$ are observations taken at a spatial distance $h$ from each other, and $\gamma(\mathrm{h})$ is called the semivariogram function.

To examine whether spatial autocorrelation occurred for yields of taro grown under both flooded conditions and upland conditions, 
$\mathrm{x}$ and $\mathrm{y}$ coordinates were determined for each plant in the $\mathrm{Cu}$ taro Trial 1 and the white taro trials. Using $\mathrm{GS}^{+}$(Version 9; Gamma Design Software, 2004), we calculated semivariograms for dry weights of corms (with rotten portions removed) for the entire experimental field and each plot.

Calculation of optimal plot size based on the power to differentiate treatments. Rather than using the method of Hatheway (1961) to determine optimal plot size and number of replications based on obtaining a certain true difference between means, we examined a whole new avenue of quantifying what is meant by "best separated." We focused on two statistical parameters related to power or the probability of finding a difference that does exist. First, the estimated difference between two treatment means divided by its SE (std_trt) is a measure of how many SDS apart are the two means. Rules of thumb for the absolute values of std_trt are: 1) 0.1 is a small difference; 2) 0.5 is medium; and 3) 1.0 is large (Cohen, 1988). Second, the probability value ( $P$ value) associated with testing treatment differences is related to power, because the proportion of times that you can reject the null hypothesis (i.e., the proportion of times that the $P$ value is less than 0.05 ) is the statistical power. In other words, the smaller the $P$ value, on average, the greater the statistical power. The plot size with the largest separation between the means (largest std_trt in absolute value) or the smallest $P$ value would be the optimal one.

\section{Results}

\section{Optimum plot size based on maximum curvature}

Copper Trial 1. Based on a graphical comparison, no obvious differences in the relationship between $\ln$ (variance) and $\ln$ (plot size) were observed between the two $\mathrm{Cu}$ treatments (control and highest $\mathrm{Cu}$ level), and the data were combined. The linear relationship based on Eq. [1] (using natural logarithms) was calculated with $r^{2}=0.97$, and the index of degree of correlation between neighboring plots ("b") was calculated as 0.87 . Maximum curvature was calculated mathematically on the nonlinear variance scale (Fig. 2, top) using Eq. [4]. An optimum plot size of 95 plants was estimated; however, this number of plants exceeded the maximum plot size and was considered to be unrealistically high.

Copper Trial 2. Similar to $\mathrm{Cu}$ Trial 1, no obvious differences in the relationship between $\ln$ (variance) and $\ln$ (plot size) were observed between the two $\mathrm{Cu}$ treatments, and thus the data were combined. The linear relationship based on Eq. [1] was calculated with $r^{2}=0.99$ and $\mathrm{b}=0.84$. Maximum curvature was estimated mathematically on the nonlinear variance scale (Fig. 2, bottom) using Eq. [4]. Optimum plot size was calculated as 21 plants (Fig. 3, top) in an area of $5.7 \mathrm{~m}^{2}$.

White taro Trial 1. Based on visual comparisons, no obvious differences were observed in the relationship between $\ln$ (variance) and $\ln$ (plot size) for the two planting dates or the

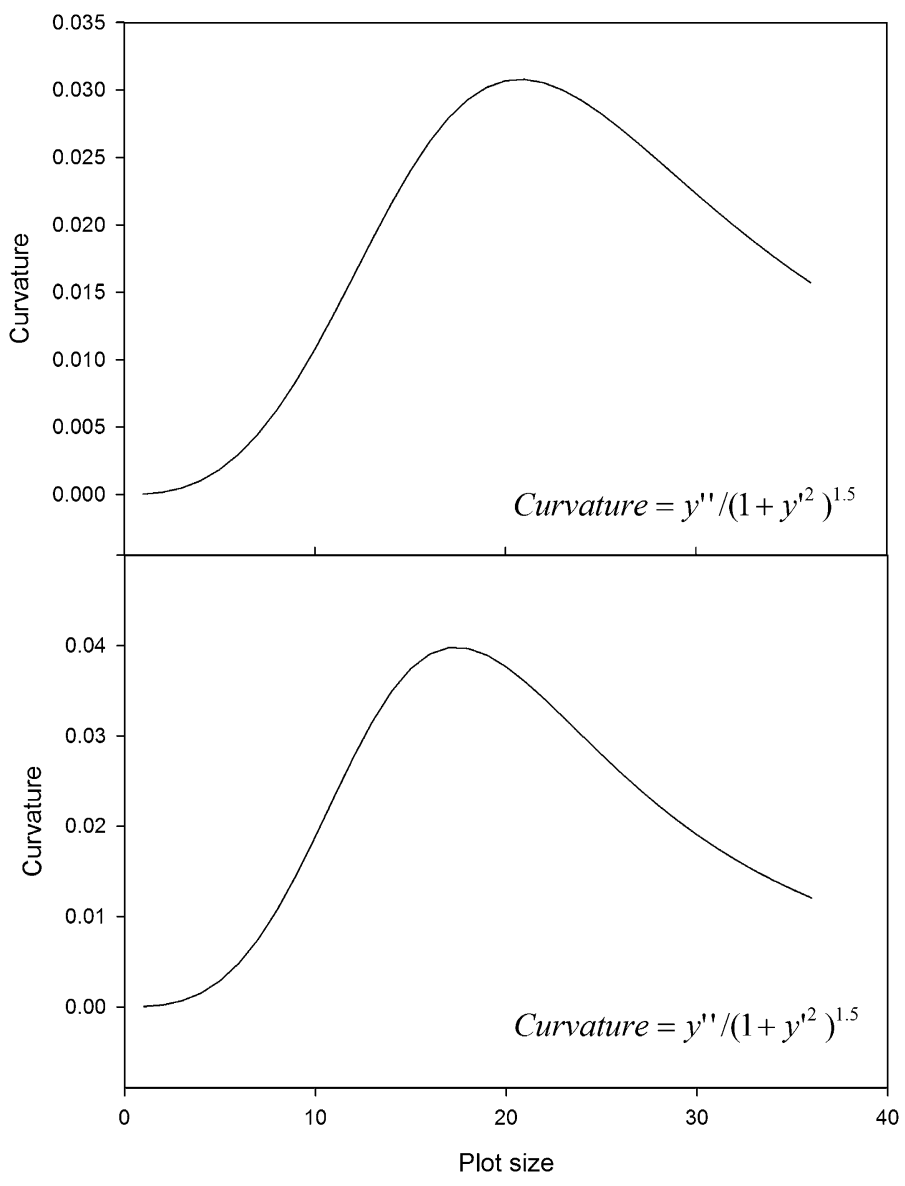

Fig. 3. Top, relationship between curvature of variance and plot size for copper $(\mathrm{Cu})$ taro Trial 2; maximum curvature is found at 21 plants. Bottom, relationship for white taro Trial 2; maximum curvature is found at 18 plants.

two taro cultivars, and the data were combined. Based on Eq. [1], the linear relationship was calculated with $r^{2}=0.97$ and $\mathrm{b}=0.76$. Maximum curvature was estimated mathematically on the nonlinear variance scale (Fig. 4, top) using Eq. [4]. Optimum plot size was calculated to be 74 plants, a number that exceeded the maximum plot size and was considered not to be feasible.

White taro Trial 2. No differences were observed in the relationship between $\ln$ (variance) and $\ln$ (plot size) between the two types of vegetative propagating materials or between the two taro cultivars, and the data were combined. The linear relationship based on Eq. [1] was calculated with $r^{2}=0.96$ and $\mathrm{b}=0.96$. Maximum curvature was estimated mathematically on the nonlinear variance scale (Fig. 4, bottom) using Eq. [4]. Optimum plot size was calculated to be 18 plants (Fig. 3, bottom) on an area of $4.9 \mathrm{~m}^{2}$.

\section{Optimum plot size based on minimized cost per unit of information}

To solve Eq. [5], the exact dimensions (d, w) of the plots must be known. Using non-linear regression (PROC GLM, Version 9.1; SAS Institute Inc., 2010), an estimate of $\lambda$ (i.e., ratio of $\mathrm{d} / \mathrm{w}$ ) of 1.5 provided a good fit to the data (Fig. 5; $r^{2}=0.82$ ). The following equation was used to approximate costs of border plants that increased with plot size:

$$
\text { Outer }=4.5 \times \sqrt{\text { Inner }}-4
$$

where Outer $=$ outer border plants minus eight, and Inner $=$ inner measured plants.

Copper Trials 1 and 2. In the two Cu trials, costs that were independent of plot size $\left(\mathrm{K}_{1}\right)$ and those dependent on plot size $\left(\mathrm{K}_{2}\right)$ were estimated at 9.86 and 2.78, respectively. Based on Eq. [2], optimum plot size for Trials 1 and 2 was calculated to be 24 and 19 inner plants, respectively, or 6.5 and $5.1 \mathrm{~m}^{2}$, respectively.

White taro Trials 1 and 2 . In the white taro trials, costs that were fixed $\left(\mathrm{K}_{1}\right)$ and those dependent $\left(\mathrm{K}_{2}\right)$ on plot size were estimated at 10.02 and 1.98, respectively. Based on Eq. [2], the optimum plot size for Trials 1 and 2 was calculated to be 16 and 121 inner plants, or 4.3 and $32.7 \mathrm{~m}^{2}$, respectively. The optimal plot size calculated for white Taro 2, was considered to be unrealistically high because it exceeded the maximum plot size.

Spatial autocorrelation of corm dry weights. Semivariograms of corm dry weights were computed for the entire field (Fig. 6, top) as well as individual plots (Fig. 6, bottom) of $\mathrm{Cu}$ Trial 1, and they exhibited essentially a pure nugget effect or a lack of spatial correlation even at the smallest possible lag spacing of $0.5 \mathrm{~m}$ (i.e., average spacing between plants). Similar results were found for $\mathrm{Cu}$ Trial 2 and white taro Trials 1 and 2 (data not shown). 
Optimum plot size based on the power to differentiate treatments

Copper Trials 1 and 2. In $\mathrm{Cu}$ Trial 1, there were not any significant treatment effects between the two levels of $\mathrm{Cu}$ (zero and eight applications). Treatment differences divided by SE were close to zero and $P$ values were quite large, indicating lack of statistical significance (Table 4). Varying the plot size had little effect on treatment differences or $P$ values. Similar results were found for $\mathrm{Cu}$ Trial 2 (data not shown).

White taro Trials 1 and 2. In white taro Trial 1, cv. Bun Long had greater corm weights than cv. Mana Lauloa. Treatment differences divided by the SE were very large (absolute values greater than 1.0) and $P$ values were near 0 , indicating statistical significance (Table 5). Varying the plot size had little effect on the large treatment differences or very significant $P$ values. Similar results were found for white taro Trial 2 (data not shown).

\section{Discussion}

To determine optimum plot size to standardize field research on taro, an optimality criterion is needed. From a statistical point of view, the optimum number of plants grown would be equal to the entire population. From a cost point of view, however, the optimum number is one. Based on the maximum curvature method (Lessman and Atkins, 1963; Meier and Lessman, 1971; Smith, 1938), the optimum plot size is the one with the fastest diminishing return of reduction in variance for increasing plot size. Using Eq. [4], optimum plot size was calculated mathematically to be 21 inner plants or $5.7 \mathrm{~m}^{2}$ in $\mathrm{Cu}$ taro Trial 2 (flooded) (Table 6). In white taro Trial 2 (upland), optimum plot size was calculated mathematically to be 18 inner plants or $4.9 \mathrm{~m}^{2}$, a result similar to that from the flooded trial.

This mathematical method of calculating maximum curvature also resulted sometimes in unrealistically high numbers when optimum plot size exceeded maximum plot size in the trials. If you examine Figures 2 and 4, you will observe that variances of $\mathrm{Cu}$ taro Trial 1 and white taro Trial 1 were a magnitude higher than those for $\mathrm{Cu}$ taro Trial 2 and white taro Trial 2. The reasons for the much lower variances per plot size in the second trials are purely speculative, but they may be related to the greater experience of agricultural technicians and increased uniformity in the management of second field trials.

Several earlier methods of estimating optimum plot size were based on visual estimations of maximum plot curvature (Boyhan et al., 2003; Vallejo and Mendoza, 1992). We recalculated the data of Boyhan et al. (2003) and found that the mathematical solution to maximum curvature differed substantially from the visual estimation. Based on our own experience, we found that the scale of variance on the y-axis could result in misleading visual estimates of maximum curvature. Mathematical calculation of maximum curvature [based on Eq. (4)] may not always result in optimum plot sizes that are feasible; however, this

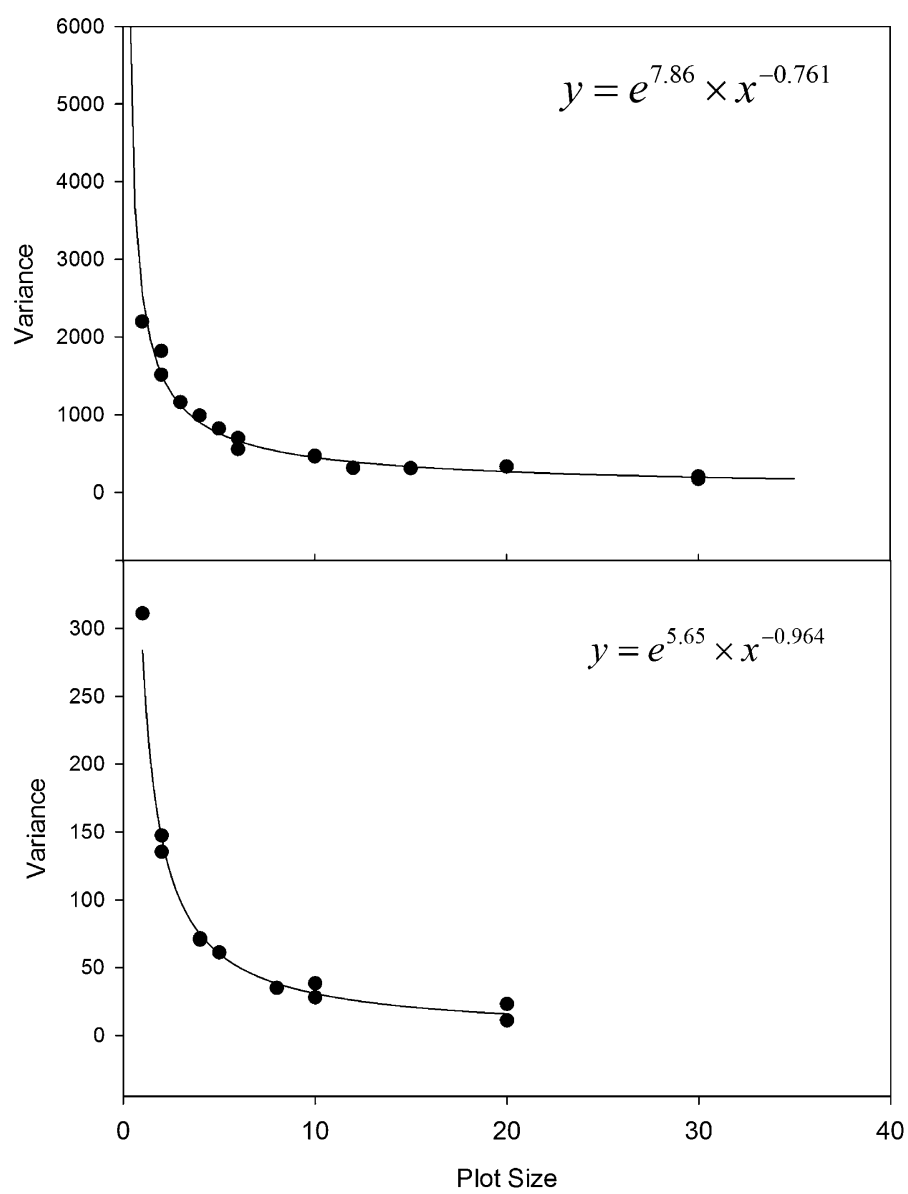

Fig. 4. Top, relationship of variance to plot size for white taro Trial 1. Bottom, relationship for white taro Trial 2. Data points are means of variance for particular plot sizes averaged across treatments.

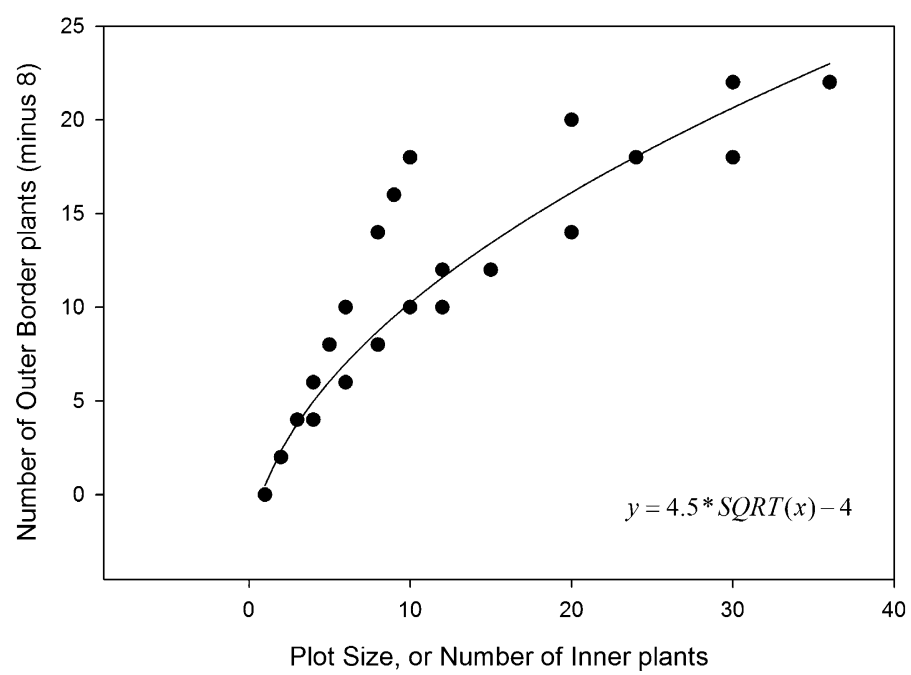

Fig. 5. Relationship of outer border plants (minus eight) to inner measured plants or plot size based on Eq [8]; $r^{2}=0.79$. Data points are outer border plants (minus eight) calculated using actual dimensions of plots [width (w), depth (d)].

method is not based on subjective, visual estimates.

Nokoe and Ortiz (1998) used segmented regression of quadratic and linear equations to calculate maximum curvature as an alternative to the subjective method of visual estimation. It was an attempt to avoid errors resulting from visual estimations; however, segmented regression does not directly estimate a point of maximum curvature and it is not obvious that a linear and quadratic equation would fit the data well in Figures 2 and 4.

A second method of determining optimum plot size is based on Eq. [2] that minimizes 
DWTCM: Isotropic Variogram
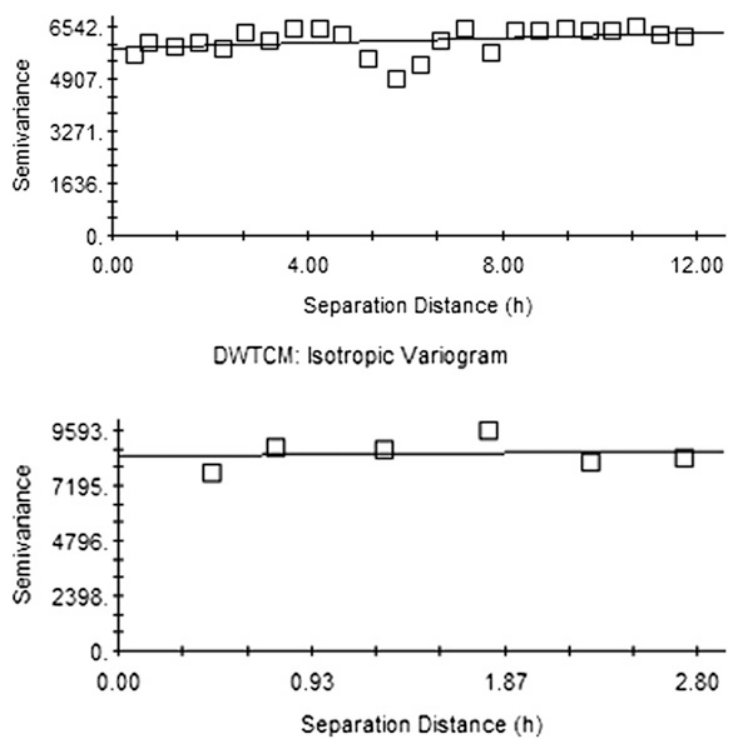

Fig. 6. Top, semivariogram plot of dry weights of corms in the entire field for copper $(\mathrm{Cu})$ taro Trial 1 ; based on a linear, isotropic model with a lag interval of $0.5 \mathrm{~m}$ (i.e., average spacing of plants); nugget variance $\left(\mathrm{C}_{\mathrm{o}}\right)=5881, \mathrm{C}_{\mathrm{o}}+$ structural variance $(\mathrm{C})=6346$; range parameter $\left(\mathrm{A}_{\mathrm{o}}\right)=11.7 ; r^{2}=0.109$; residual sums of squares $(\mathrm{RSS})=3,648,013$. Bottom, semivariogram plot of dry weights of corms in plot $\mathrm{D} 1$ for $\mathrm{Cu}$ taro Trial 1; based on a linear, isotropic model with a lag interval of $0.5 \mathrm{~m} ; \mathrm{C}_{\mathrm{o}}=8491$, sill $\mathrm{C}_{\mathrm{o}}+\mathrm{C}=8710 ; \mathrm{A}_{\mathrm{o}}=2.73 ; r^{2}=0.013 ; \mathrm{RSS}=1,915,882$.

Table 4. Effect of plot sizes in $\mathrm{Cu}$ taro Trial 1 on mean differences between two treatments divided by its SE (std_trt) and the associated $P$ values.

\begin{tabular}{lrc}
\hline Plot size (no. of plants) & Std_trt & $P$ value \\
\hline 1 & -0.0032 & 0.970 \\
2 & 0.2478 & 0.837 \\
3 & -0.2013 & 0.893 \\
4 & 0.0099 & 0.954 \\
6 & 0.0111 & 0.960 \\
8 & -0.0085 & 0.973 \\
9 & -0.0306 & 0.913 \\
12 & -0.0002 & 0.999 \\
18 & -0.0126 & 0.978 \\
24 & -0.0135 & 0.979 \\
36 & -0.0002 & 0.999 \\
\hline
\end{tabular}

$\mathrm{Cu}=$ copper.

Table 5. Effect of plot sizes in white taro Trial 1 on mean differences between two treatments divided by its SE (std_trt) and the associated $P$ values.

\begin{tabular}{lcc}
\hline Plot size (no. of plants) & Std_trt & $P$ value \\
\hline 1 & -1.24 & 0 \\
2 & -1.43 & 0 \\
2 & -1.51 & 0 \\
3 & -1.63 & 0 \\
4 & -1.98 & 0 \\
5 & -1.57 & 0 \\
6 & -2.17 & 0 \\
6 & -1.89 & 0 \\
10 & -2.57 & 0 \\
10 & -1.80 & $<0.0001$ \\
12 & -2.74 & 0 \\
15 & -2.11 & $<0.0001$ \\
20 & -3.48 & 0 \\
30 & -2.81 & $<0.0001$ \\
30 & -4.04 & 0 \\
\hline
\end{tabular}

the cost per unit of information (Smith, 1938). In the two $\mathrm{Cu}$ taro Trials, optimal plot size was estimated at 24 and 19 inner plants, respectively, or 6.5 and $5.1 \mathrm{~m}^{2}$, respectively (Table 6). In white taro Trial 1, optimal plot size was estimated at 16 inner plants or $4.3 \mathrm{~m}^{2}$. In white taro Trial 2, optimum plot size was estimated at 121 plants or $32.7 \mathrm{~m}^{2}$. This larger estimated plot size was the result of an estimated "b" from Eq. [1] of nearly one. Such a large value could have been the result of the high mortality rate caused by drought stress in these rainfed plants. It indicates that the variance decreases about proportional to the inverse of the plot size, which corresponds to about independent neighboring plots. When adjacent plots are about independent and when per plot costs are a significant fraction of overall costs (Table 3 ), then it is cost-effective to increase the plot size. This finding is consistent with Lin and Binns (1986), who concluded that if $b>0.7$, then plot size should be increased to improve the efficiency and accuracy of a randomized complete block design.

The first two methods assume that "b" from Eq. [1] is constant; however, if spatially structured variation is strong, then this assumption is incorrect. A third method of estimating optimum plot size involves conditional stochastic simulations of various plot configurations and calculations of semivariograms for each plot (Fagroud and Van Meirvenne, 2002). However, based on geostatistical analysis of yields in $\mathrm{Cu}$ Trial 1 (Fig. 6), $\mathrm{Cu}$ Trial 2 (data not shown), and both white taro trials (data not shown), there was no evidence of spatial autocorrelation. It was decided that the two classical methods of optimal plot determination were sufficient under these flooded and upland field conditions.

The fourth method of determining optimal plot size was based on the power of differentiating treatments. Unfortunately, this power analysis based on yield data for the four trials was not very informative for determining optimal plot size. In $\mathrm{Cu}$ taro Trials 1 and 2, there were not any significant treatment effects resulting from the application of $\mathrm{Cu}$, even at the largest plot size. In white taro Trials 1 and 2 , the opposite situation was found with large differences between cultivars and highly significant $P$ values associated with treatment differences even at a plot size of one inner measured plant. To use this fourth method, an ideal experiment would be one with borderline statistically significant differences between treatments so that varying the plot size would make a difference.

In the introduction, we proposed three hypotheses about optimum plot size. Our first hypothesis that flooded culture would reduce plant stress, yield variance, and hence decrease optimum plot size was not supported by our research findings (Table 6). Using the maximum curvature method, optimal plot size was calculated to be 18 inner plants grown under upland culture and 21 inner plants grown in flooded culture. Similarly, using the method of minimized cost per unit of information, optimal plot size was 16 inner plants grown under upland culture, whereas it ranged from 19 to 24 inner plants under flooded culture.

Our second hypothesis that variance of yield in relation to plot size would vary between cultivars was not supported by our results. In the white taro trials, no obvious differences were found in the linear relationship between $\ln$ (variance) and $\ln$ (plot size) for each cultivar, and the data were combined for the maximum curvature analysis. In addition, the average optimum plot size was similar for the $\mathrm{Cu}$ trials and the white taro trials although each set of trials contained different cultivars (Tables 1 and 6). These taro cultivars varied from two Hawaiian cultivars (Maui Lehua in the $\mathrm{Cu}$ trials and Mana Lauloa in the white taro trials) to the Chinese cultivar Bun Long in the White Taro Trials, providing a wide range in genetic variability. These results indicate that this optimum plot size would be appropriate for research trials evaluating cultivar differences.

Our third hypothesis that tissue-cultured plants would exhibit a smaller variance compared with traditional planting materials ("huli") was not supported by evidence in white taro Trial 2. No obvious differences were found in the relationship between $\ln$ (variance) and $\ln$ (plot size) for the two vegetative propagating materials and the data were combined in the maximum curvature method.

There is no literature reporting on calculations of optimum plot size for taro; the closest crop species could be the tropical root crop sweetpotato that also is propagated vegetatively. Using the maximum curvature method, optimum plot size of the tropical root crop sweetpotato was visually estimated to be 30 to 60 plants on 6 to $12 \mathrm{~m}^{2}$ depending on 
Table 6. Comparison of parameters (e.g., b, $\mathrm{K}_{1}$, and $\mathrm{K}_{2}$ ) calculated for four field trials and optimal plot sizes (number of inner plants) based on two methods (e.g., maximum curvature and minimized cost per unit of information.

\begin{tabular}{lccccc}
\hline Field trial & $\mathrm{b}$ & $\mathrm{K}_{1}$ & $\mathrm{~K}_{2}$ & Opt. plot size $^{\mathrm{z}}$ & Opt. plot size $^{\mathrm{y}}$ \\
\hline Cu taro 1 & 0.87 & 9.86 & 2.78 & 95 & 24 \\
Cu taro 2 & 0.84 & 9.86 & 2.78 & 21 & 19 \\
White taro 1 & 0.76 & 10.02 & 1.98 & 74 & 16 \\
White taro 2 & 0.96 & 10.02 & 1.98 & 18 & 121 \\
\hline
\end{tabular}

${ }^{\mathrm{z} B a s e d}$ on maximum curvature method.

${ }^{y}$ Based on minimized cost per unit of information.

$\mathrm{Cu}=$ copper.

cultivar (Vallejo and Mendoza, 1992). Optimum plot size of taro (based on number of plants) appeared to be half to one-third smaller relative to sweetpotato. Interestingly, a sweetpotato researcher (A. Villordon, personal communications, 2012) reported that he used a smaller plot size of 10 sweetpotato plants surrounded by one to two border rows as a result of the difficulty in ensuring the uniformity of vegetative planting materials and soil conditions in larger-sized plots.

Based on results from the first two methods, an optimal plot size of 16 to 24 inner plants ( 4.3 to $6.5 \mathrm{~m}^{2}$ ) is recommended for field trials of taro. These recommendations are based on use of border rows surrounding inner measured plants. Interestingly, in white taro Trial 1, the fourth method of using power analysis to estimate optimal plot size indicated that highly significant differences between cultivars were found even at a plot size of one inner measured plant (Table 5).

Future research needs to examine whether border rows are necessary in field trials that evaluate taro cultivars. For example, Zuhlke and Gritton (1969) showed little difference in their calculations of optimum plot sizes for pea in guarded plots $\left(3.3 \mathrm{~m}^{2}\right)$ vs. unguarded plots $\left(3.1 \mathrm{~m}^{2}\right)$. In sugarcane (Saccharum $\mathrm{spp}$.) selection trials, plot sizes that ranged between 1.82 and $4.88 \mathrm{~m}$ single-row plots were not found to affect the ability to confidently retain the top $1 \%$ of the genotypes evaluated (Milligan et al., 2007). In contrast, in trials of rainfed, lowland rice (Oryza sativa) genotypes, yields of two-row plots were unreliable at a high soil fertility location, because tall genotypes shaded short genotypes (Jearakongman et al., 2003). Based on visual observations of taro field trials, cultivars that differed in disease resistance and height could affect adversely the growth of neighboring cultivars within a row, although effects on plants in the next row depended on row width.

\section{Conclusions}

Our results indicated that 16 to 24 inner measured taro plants could be considered the smallest optimum plot size. However, if finances or space are limiting and if treatment differences are great enough, then it is possible that fewer inner measured taro plants could suffice to test for differences. These recommendations are based on the presence of random spatial variability in the field. At this time, it is recommended that these inner measured plants should be surrounded by border rows.

\section{Literature Cited}

Boyhan, G.E., D.B. Langston, A.C. Purvis, and C.R. Hill. 2003. Optimum plot size and number of replications with short-day onions for yield, seedstem formation, number of doubles, and incidence of foliar diseases. J. Amer. Soc. Hort. Sci. 128:409-424.

Cohen, J. 1988. Statistical power analysis for the behavioral sciences. ${ }^{\text {nd }}$ Ed. Lawrence Erlbaum Assoc., Hillsdale, NJ.

Ellis, R. and D. Gulick. 1972. Calculus and analytic geometry, Alt Ed. Addison-Wesley, Reading, MA. p. 598.

Fagroud, M. and M. Van Meirvenne. 2002. Accounting for soil spatial autocorrelation in the design of experimental trials. Soil Sci. Soc. Amer. J. 66:1134-1142.

Food and Agriculture Organization of the United Nations. 2012. 18 Mar. 2013. <http://faostat3. fao.org/home/index.html>.

Gamma Design Software. 2004. GS+: Geostatistics for the environmental sciences. Gamma Design Software, Plainwell, MI.

Hatheway, W.H. 1961. Convenient plot size. Agron. J. 53:279-280.

Ikawa, H., H.H. Sato, A.K.S. Chang, S. Nakamura, E. Robello, Jr., and S.P. Periaswamy. 1985. Soils of the Hawaii Agricultural Experiment
Station, University of Hawaii: Soil survey, laboratory data, and soil descriptions. Res. Ext. Ser. 022. Univ. Hawaii, Coll. Trop. Agr. Human Resources, Honolulu, HI

Jearakongman, S., S. Immark, A. Noenplub, S. Fukai, and M. Cooper. 2003. Effect of plot size on accuracy of yield estimation of rainfed lowland rice genotypes with different plant heights and grown under different soil fertility conditions. Plant Prod. Sci. 6:95-102.

Lessman, K.J. and R.E. Atkins. 1963. Optimum plot size and relative efficiency of lattice designs for grain sorghum yield tests. Crop Sci. 3:477481.

Lin, C.S. and M.R. Binns. 1986. Relative efficiency of two randomized block designs having different plot sizes and numbers of replications and of plots per block. Agron. J. 78:531-534.

Meier, V.D. and K.J. Lessman. 1971. Estimation of optimum field plot shape and size for testing yield in Crambe abyssinica Hochst. Crop Sci. 11:648-650.

Milligan, S.B., M. Balzirini, K.A. Gravois, and K.P. Bischoff. 2007. Early stage sugarcane selection using different plot sizes. Crop Sci. 47:1859-1864.

National Resource Conservation Service. 2012. 17 Mar. 2012. http://websoilsurvey.nrcs.usda.gov/ app/HomePage.htm.

Nokoe, S. and R. Ortiz. 1998. Optimum plot size for banana trials. HortScience 33:130-132.

Plucknett, D.L., R.S. de la Pena, and F. Obrero. 1970. Taro (Colocasia esculenta). Field Crops Abstr. 23:413-426.

SAS Institute Inc. 2010. SAS/ STAT 9.2 user's guide. $2^{\text {nd }} \mathrm{Ed}$. SAS Institute Inc., Cary, NC.

Smith, H.F. 1938. An empirical law describing heterogeneity in the yields of agricultural crops. J. Agric. Sci. 28:1-23.

Standal, B.R. 1983. Nutritive value, p. 141-147. In: Wang, J.K. (ed.). Taro: A review of Colocasia esculenta and its potentials. University of Hawaii Press, Honolulu, HI.

Swallow, W.H. and T.C. Wehner. 1986. Optimum plot size determination and its application to cucumber yield trials. Euphytica 35:421-432.

Vallejo, R.L. and H.A. Mendoza. 1992. Plot technique studies on sweet potato yield trials. J. Amer. Soc. Hort. Sci. 117:508-511.

van Es, H.M. and C.L. van Es. 1993. Spatial nature of randomization and its effect on the outcome of field experiments. Agron. J. 85:420-428.

Zhang, R., A.W. Warrick, and D.E. Meyers. 1990. Variance as a function of sample support size. Math. Geol. 22:107-121.

Zucker, D.M. 2005. Information. In: Encyclopedia of biostatistics. Online. John Wiley \& Sons, Ltd. 6 Aug. 2012. <http://onlinelibrary.wiley.com/ book/10.1002/0470011815>.

Zuhlke, T.A. and E.T. Gritton. 1969. Optimum plot size and shape estimates for pea yield trials. Agron. J. 61:905-908. 